\title{
Factors Influencing Breast Cancer Genetic Testing Among High Risk African American Women: A Systematic Review
}

\author{
Shirley Ann Spencer \\ Governors State University, sspencer@govst.edu \\ Carolyn Rodgers \\ Governors State University, cestes@govst.edu \\ Vickii Coffey \\ Governors State University, vcoffey@govst.edu
}

Follow this and additional works at: https://nsuworks.nova.edu/ijahsp

Part of the Women's Health Commons

This Systematic Review has supplementary content. View the full record on NSUWorks here: https://nsuworks.nova.edu/ijahsp/vol17/iss4/1

\section{Recommended Citation}

Spencer SA, Rodgers C, Coffey V. Factors Influencing Breast Cancer Genetic Testing Among High Risk African American Women: A Systematic Review. The Internet Journal of Allied Health Sciences and Practice. 2019 Jan 01;17(4), Article 1.

This Systematic Review is brought to you for free and open access by the College of Health Care Sciences at NSUWorks. It has been accepted for inclusion in Internet Journal of Allied Health Sciences and Practice by an authorized editor of NSUWorks. For more information, please contact nsuworks@nova.edu. 


\title{
Factors Influencing Breast Cancer Genetic Testing Among High Risk African American Women: A Systematic Review
}

\begin{abstract}
African American women are disproportionately impacted by breast cancer and its associated effects. They have the highest breast cancer mortality rate of all racial and ethnic groups in the U.S., yet, many high risk African American women do not follow-up with genetic testing despite, having a shorter survival rate and more likely to develop malignancies or aggressive forms of breast cancer than white women. Purpose: This review explored breast cancer genetic follow up and barriers among African American women and made recommendations for designing tailored high risk breast cancer programs. Method: The Integrative Model of Behavioral Prediction framework provided the framework for the review. PubMed, PSYINFO, CINAHL and Cochrane Collection Plus databases were searched for articles published from 2007 to 2017 that focused on attitude and beliefs that influenced genetic testing follow up among African American women. Three reviewers independently reviewed and appraised articles. The quality of the articles was assessed to determine the evidence level and overall recommendations using the Joanna Bridge Institute grading criteria. Results: Sixteen of the 2275 articles reviewed met the inclusion criteria of which, seven showed statistically significance changes related to family concerns, medical mistrust and cost barriers; decreases in breast cancer worry and perceived risk after genetic counseling; and higher education level and diagnosed early increased genetic testing. Conclusions: This systematic review provides greater understanding of how the social determinants of health influence decisions about genetic testing and treatment to determine why African American women who are at risk for breast cancer, do not progress to genetic testing. It provided recommendations for designing sensitive curriculum content for African American women and providers to increase genetic follow-up and reduce breast cancer disparity. The results of this review could be used to design comprehensive, tailored interventions to address the identified barriers, increase breast cancer awareness and early detection, and help minority women make informed, value decisions about genetic testing and treatment options. Recommendations: Future research is required to examine the role communities, agencies and policy makers play in improving clinical outcomes for minorities.
\end{abstract}

\section{Author Bio(s)}

Shirley Spencer, PhD, MSN, is an Assistant Professor of Nursing in the College of Health and Human Services at Governors State University in University Park, IL. She is also a licensed registered nurse in the state of Illinois.

Carolyn Rodgers, PhD, MPH, MHS, MCHES, is a Senior Lecturer of Addiction Studies Behavioral Health in the College of Health and Human Services at Governors State University in University Park, IL. She is a Division Board member for Professional Preparation and Practice for the National Commission for Health Education Credentialing.

Vickii Coffey, PhD, MSA, is an Assistant Professor of Social Work in the College of College of Health and Human Services at Governors State University, University Park, Illinois.

\section{Acknowledgements}

We gratefully acknowledge Dr. Catherine Tymkow, Governors State University. She critically reviewed the manuscript and made helpful suggestions. We gratefully acknowledge Dr. Kent Hoskins, oncologist and Director of the University of Illinois, Chicago Familial Breast Cancer Program, who suggested the concept for this review.

This systematic review is available in Internet Journal of Allied Health Sciences and Practice: https://nsuworks.nova.edu/ijahsp/vol17/iss4/1 


\title{
IJAHSP \\ The Internet Joưnal of Allied Health Sciences and Practice
}

Dedicated to allied health professional practice and education

Vol. 17 No. 4 ISSN 1540-580X

\section{Factors Influencing Breast Cancer Genetic Testing Among High Risk African American Women: A Systematic Review}

\author{
Shirley Ann Spencer \\ Carolyn Rodgers \\ Vickii Coffey \\ Governors State University \\ United States
}

\begin{abstract}
Background: African American women are disproportionately impacted by breast cancer and its associated effects. They have the highest breast cancer mortality rate of all racial and ethnic groups in the U.S., yet, many high risk African American women do not follow-up with genetic testing despite having a shorter survival rate and being more likely to develop malignancies or aggressive forms of breast cancer than White women. Purpose: This review explored breast cancer genetic follow up and barriers among African American women and made recommendations for designing tailored high risk breast cancer programs. Method: The Integrative Model of Behavioral Prediction framework provided the framework for the review. PubMed, PSYINFO, CINAHL and Cochrane Collection Plus databases were searched for articles published from 2007 to 2017 that focused on attitude and beliefs that influenced genetic testing follow up among African American women. Three reviewers independently reviewed and appraised articles. The quality of the articles was assessed to determine the evidence level and overall recommendations using the Joanna Briggs Institute grading criteria. Results: Sixteen of the 2275 articles reviewed met the inclusion criteria, of which seven showed statistically significant changes related to family concerns, medical mistrust, and cost barriers; decreases in breast cancer worry and perceived risk after genetic counseling; and higher education level and diagnosed early increased genetic testing. Conclusions: This systematic review provides greater understanding of how the social determinants of health influence decisions about genetic testing and treatment to determine why African American women who are at risk for breast cancer do not progress to genetic testing. It provided recommendations for designing sensitive curriculum content for African American women and providers to increase genetic follow-up and reduce breast cancer disparity. The results of this review could be used to design comprehensive, tailored interventions to address the identified barriers, increase breast cancer awareness and early detection, and help minority women make informed, value decisions about genetic testing and treatment options. Recommendations: Future research is required to examine the role communities, agencies, and policy makers play in improving clinical outcomes for minorities.
\end{abstract}

Keywords: breast cancer, genetic test, African American women, barriers, attitude/beliefs, social determinants of health 


\section{INTRODUCTION}

In the United States, breast cancer is the most common cancer among women of all races/ethnicities and the second leading cause of cancer deaths. ${ }^{1}$ Although more White women (WW) are diagnosed with breast cancer, African American women (AAW) are disproportionately impacted by breast cancer and its associated effects. They have the highest breast cancer mortality rate of all racial and ethnic groups, have a higher occurrence of breast cancer before age 50 , are diagnosed later, have a shorter survival rate, are affected by earlier-onset and aggressive, are difficult to treat triple-negative breast cancer (TNBC), and are more likely to have malignant genetic variants than WW. ${ }^{2-4}$

Early detection and prompt treatment have been demonstrated to reduce breast cancer mortality and extend or improve quality of life. ${ }^{5}$ However, many AAW with breast cancer miss opportunities for early interventions. Underutilization and irregular utilization of breast cancer screening among AAW may contribute to the disparities in survival and mortality rates. 6,7 This reduced adherence to breast cancer screening guidelines leads to later stage cancer diagnoses in AAW, a factor correlated with lower survival rates.8,9 Even a three-month treatment delay can contribute to breast cancer mortality. ${ }^{10}$ One study reported only $64 \%$ of AAW aged 40 years and over adhere to recommendations for annual clinical breast examination; even fewer (50\%) reported adhering to the most effective early detection, risk reducing, and clinical management strategies. ${ }^{5}$

An estimated $5 \%-10 \%$ of breast cancers are hereditary, and primarily attributed to BRCA1 or BRCA2 gene mutations. ${ }^{1}$ Although the population of AAW who have these gene mutations is low, risk assessment through genetic counseling and testing is vital. It provides the opportunity to gain early access to preventative and specialized care and provides them with information to make valued informed health care decisions. Women with a personal history of breast cancer have a $55 \%-85 \%$ lifetime risk. Women with $B R C A 1$ or $B R C A 2$ mutation have a distinctly increased risk for the disease, especially for women age 40 and younger.11,12 Furthermore, women with a BRCA1 mutation have a lifetime risk as low as $31 \% .{ }^{2,13}$ The prevalence of the disease increases as the mutated gene is passed on to their children.

\section{Social Determinants of Health (SDOH)}

The SDOH-economic stability, health literacy/education, social and community context, healthcare system, and neighborhood and built environments play a key role in the uptake of genetic testing., 6,14 Approximately $85 \%$ of all breast cancer is nonhereditary and associated with the $\mathrm{SDOH}_{2}, 3,15$ Although there is a critical need to conduct more genetic testing among AAW diagnosed with breast cancer, evidence suggests that many high-risk AAW do not follow-up with testing because of barriers related to the SDOH. 16 Barriers such as limited health literacy and psychological distress associated with inability to understand genetic information, access to healthcare services, ineffective communication, attitude and cultural beliefs, family, and socioeconomic status may explain why AAW are hesitant to follow-up. ${ }^{5}$ One study suggests that AAW with breast cancer are $78 \%$ less likely to undergo genetic screening and testing as compared to WW with comparable histories because of socioeconomic factors, risk perception, attitudes, or primary care physician recommendations. ${ }^{17}$

Although numerous studies support the benefits of genetic screening and testing for breast cancer genetic variants, little is known about AAW's attitudes or recent experiences with genetic testing, why many do not progress to testing, or why interventions to increase genetic testing have been implemented, but with little progress. ${ }^{1,10}$ The aim of this systematic review is to synthesize current evidence exploring breast cancer genetic testing follow up and barriers from the perspective of AAW and make recommendations to consider when designing tailored high-risk breast cancer programs.

\section{Theoretical Framework}

The Integrative Model of Behavioral Prediction (IMBP) framework provided the framework for the review. This model postulates that intentions are the strongest predictor of behavior, and individuals will act on them when they have the essential skills and environmental constraints do not impede behavioral performance..$^{18}$ The intentions are formed by the interactions of perceived social norm, attitude and self-efficacy. The association between background factors and behavior depicts the flexibility and adaptability of the model to varied cultures, contexts, and diverse populations.

According to the IMBP, the intention to pursue genetic screening and testing can be influenced by attitudes, beliefs about social norms, and control beliefs (self-efficacy). Also, the IMBP evaluates the effects of barriers that may influence an individual's decision to progress to genetic screening and testing. The model provides opportunities for tailored educational intervention to help women diagnosed with breast cancer understand genetic screening and testing, improve the accuracy of risk perception, and address psychosocial aspects and information to facilitate informed health care decisions. 


\section{METHODS}

The systematic approach, consisting of input-searching the literature, throughput- processing the literature, and output- writing the review was employed. A combination of quantitative and qualitative reviews is included to develop a deeper understanding of the socio-psychological and experiential phenomenon of why AAW diagnosed with breast cancer do not follow-up with genetic testing.

\section{Search Strategy}

The search was conducted using PubMed, CINAHL, PSYINFO, and Cochrane Collection Plus strategies using a combination of the following subject headings and keywords: "breast cancer barriers" AND "genetic testing," "breast cancer genetic testing AND "AAW barriers," and "breast cancer genetic testing" AND "African Americans' attitudes." The search was limited to English language articles from 2007 to 2017. Studies published prior to the year 2007 were excluded because they were not reflective of the existing breast mortality and survival rates, advanced treatments, and progress. The search was designed to retrieve various subtopics within the main topic, including beliefs and perceptions.

\section{Study Selection}

Three authors conducted the search, coded the studies, and independently reviewed the coded studies. Disagreements among the coders and the reviewers were discussed until agreement was reached among all authors. We conducted a three-stage screening process beginning with a title review, abstract review, and full text article review to determine eligibility.

\section{Data Abstraction and Tabulation}

Articles details were abstracted using data abstraction forms to collect data and create reports on the year of publication, study design, sample size, population, focus, measures, grading quality, and recommendations.

\section{Quality Assessment and Grading}

The process of the grading of evidence is depicted in Table 1. The validity of the articles selected for the review was assessed using a modified Joanna Briggs Institute (JBI) grading of evidence level for effectiveness and meaning. ${ }^{19}$ Quantitative studies were assessed and rated according to five levels of effectiveness, and qualitative studies were rated according to five levels of meaningfulness. Quantitative studies were assessed and rated according to five levels of effectiveness, with level one experimental design, representing the strongest evidence and level 5-expert opinion and bench research, representing the weakest evidence. Qualitative studies were rated according to five levels of meaningfulness, with level 1-qualitative or mixed methods systematic reviews and level 5 -expert opinion, representing the least meaningfulness

Table 1. JBI Level of Evidence Scales for Effectiveness and Meaningfulness

\begin{tabular}{|l|}
\hline \multicolumn{1}{|c|}{ Levels of Evidence } \\
\hline Effectiveness \\
Level 1: Experimental design \\
Levels 2: Quasi-experimental design, \\
Levels 3: Observational,-analytic design \\
Levels 4: Observational,-descriptive design \\
Levels 5: Expert opinion and bench research \\
\hline Meaningfulness \\
Level 1: Qualitative or mixed methods systematic reviews \\
Level 2: Qualitative or mixed methods synthesis \\
Level 3: Single qualitative study \\
Level 4 Systematic review of expert opinion \\
Level 5: Expert opinion
\end{tabular}

Adapted with permission The Joanna Briggs Institute Levels of Evidence and Grades of Recommendation. ${ }^{19}$ 
The JBI Grades of Recommendations were used to integrate the best available evidence on breast cancer genetic test follow up and barriers from the perspective of AAW and make evidence-based recommendations for designing tailored risk breast cancer programs (See Table 2). The JBI has two grades for recommendations: Grade A is a strong recommendation and Grade B is a weak recommendation. ${ }^{19}$ All studies are evaluated using the FAME (feasibility, appropriateness, meaningfulness, and effectiveness) scale developed by the JBI. ${ }^{19}$

Table 2. Grades of Recommendation

\begin{tabular}{|c|l|}
\hline Grade & \multicolumn{1}{c|}{ Definition } \\
\hline A & $\begin{array}{l}\text { 'Strong' recommendation. (1) Desirable effects outweigh undesirable effects of the health management strategy; } \\
\text { (2) evidence of adequate quality supporting its use; (3) there is a benefit or no impact on resource use, and (4) } \\
\text { values, preferences and the patient experience have been taken into account. }\end{array}$ \\
\hline B & $\begin{array}{l}\text { 'Weak' recommendation (1) desirable effects appear to outweigh undesirable effects of the health management } \\
\text { strategy, though not clear; (2) evidence supporting its use, even though this may not be of high quality; (3) there } \\
\text { is a benefit, no or minimal impact on resource use, and (4) values, preferences and the patient experience may or } \\
\text { may not have been taken into account. }\end{array}$ \\
\hline
\end{tabular}

Adapted with permission The Joanna Briggs Institute Levels of Evidence and Grades of Recommendation. ${ }^{19}$

\section{RESULTS}

\section{Search Results}

The search identified 2275 distinctive articles. The title and abstract screens were retained. Of these, 86 articles were selected for further consideration, and 2163 articles were removed after accounting for duplication or did not include breast cancer genetic test or classify race/ethnicity. Of the remaining 30 articles, 14 articles did not include barriers to breast cancer genetic test, African American beliefs, attitudes, or perceptions or meet the African American 10\% minimum sampling requirement. Full text screening with reference list searching identified 16 articles that met the target criteria. The article selection process is depicted in Figure 1. Articles included in the review met the study inclusion and exclusion criteria (See Table 3).

Table 3. Study Inclusion and Exclusion Criteria

\begin{tabular}{|l|l|}
\hline Inclusion Criteria & Exclusion Criteria \\
\hline 1. Studies in English & 1. Studies not in English \\
\hline 2. Peer reviewed studies & 2. Studies more than 10 years old \\
\hline 3. Studies published from 2007-2017 & 3. Studies not in the United States \\
\hline $\begin{array}{l}\text { 4. Studies included African American women } \\
\text { sample }\end{array}$ & 4. Race/ethnicity is not classified \\
\hline $\begin{array}{l}\text { 6. Examined or explored attitudes, perceptions, beliefs or } \\
\text { barriers related to genetic testing }\end{array}$ & $\begin{array}{l}\text { 5. African American women participants were }<10 \% \text { of } \\
\text { sample }\end{array}$ \\
\hline
\end{tabular}




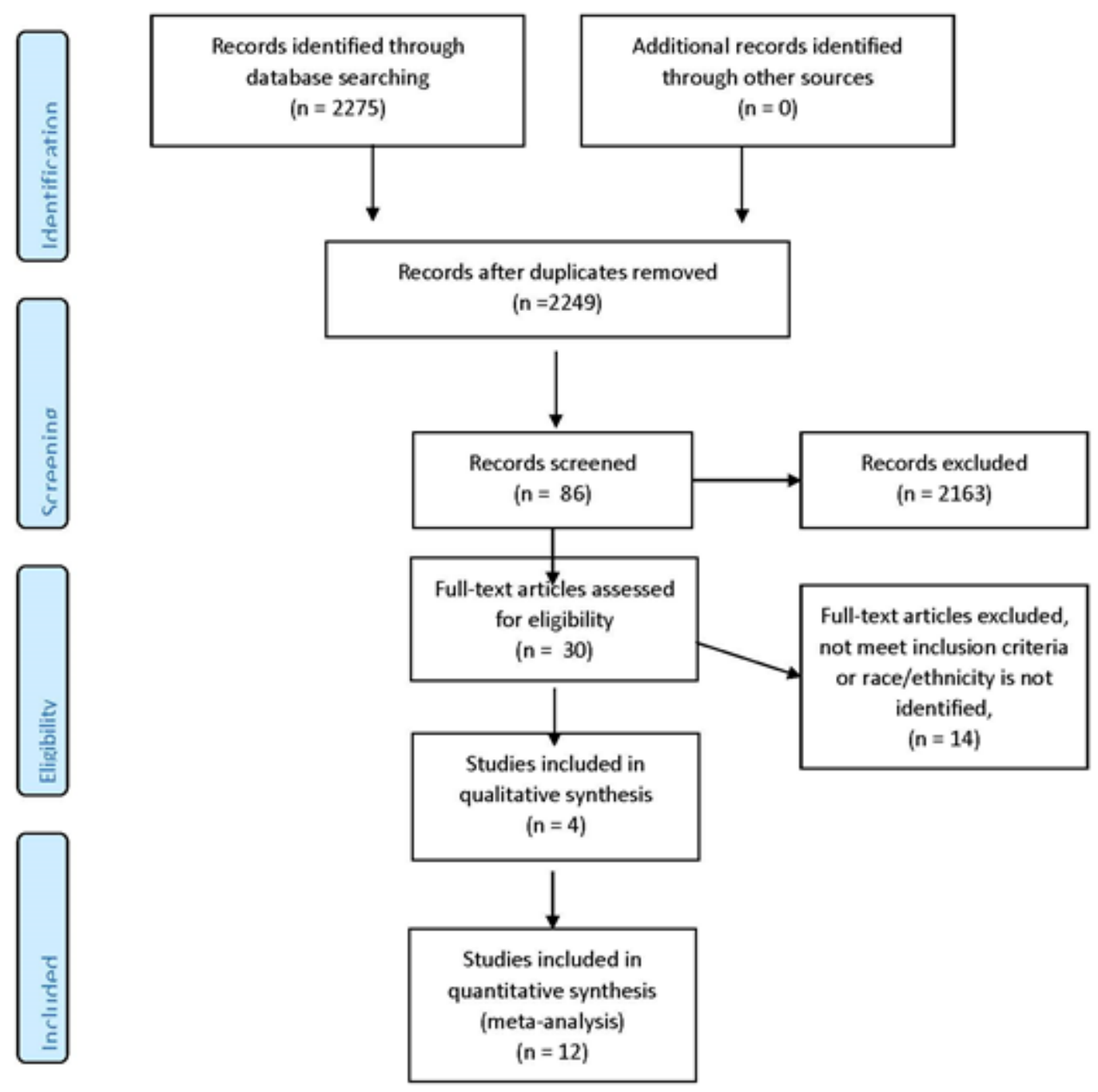

Figure 1. PRISMA flowchart of eligible studies20

\section{Characteristics of the Study Samples}

Characteristics identified and summary of review are presented in Table 4 (see Appendix A). Sixteen quantitative and qualitative studies comprised this review. Twenty-five percent of the studies collected data using qualitative designs, $25 \%$ used cross sectional designs, $12 \%$ used secondary analysis, $6 \%$ used randomized trial design, $6 \%$ used retrospective design, $6 \%$ used systematic review design, $6 \%$ used integrative review design, $6 \%$ used prospective analysis design, and $6 \%$ used a descriptive design. Of these studies, eleven studies included samples comprised of AAW, two included $18 \%$ or less AAW, one study included $24 \%$, one study included $26 \%$, and another included $65 \%$. Ten studies included all adults, one study classified the sample as below age 50, one study classified the sample as age 20-69, one study classified the sample as mean age 52 , one study classified the sample as age 25-49, one study classified the sample as age 20-45, and one study classified the sample as age 21 and older. The most common outcomes in the studies reviewed were breast cancer-related beliefs, attitudes and perceptions (psychosocial,), knowledge and perceived risk (cognitive), and health care system. 


\section{Beliefs, Attitudes, and Perceptions (psychosocial factors)}

Most of the women reported interest in genetic testing and associated breast cancer-related beliefs, attitudes, or perceptions with knowledge and perceived risk as primary outcomes. Benefits to genetic screening and testing included providing education to raise breast cancer awareness, information to prevent breast cancer, and information to make informed decisions (18\%). Two out of sixteen articles $(12 \%)$ cited physician recommendation as motivators to progress to genetic testing. The four studies that assessed religion and spirituality reported a possible association with coping, hope, and genetic follow up.

\section{Knowledge and Perceived Risk (cognitive)}

Lack of knowledge of breast cancer and risk factors were negatively associated with genetic testing follow up. Half of the studies reported low and inaccurate breast cancer knowledge among AAW. One study suggested that minority women have low levels of genetic testing awareness, and this influenced their decision to progress to genetic counseling/genetic testing. Another study explored misunderstanding about genetic tests. Most participants lacked knowledge about genetic tests and believed the tests are more predictive than they actually are. Only one study reported no clear association between feeling susceptible to getting breast cancer and the likelihood of being in a group that received or did not receive breast cancer genetic counseling.

\section{Barriers}

A summary of barriers is presented in Table 5 . All studies assessed the healthcare system and reported barriers to genetic testing follow up and treatment. Barriers identified from the review are classified according to the SDOH. These barriers experienced by AAW were associated with economic stability, education, social and community context, the health care system, and neighborhood and built environments. The economic stability determinant focused on employment and income including constraints beyond the individual's ability to pay for services and work conflict. Education focused on health literacy and education level including lack of knowledge about genetic counseling/testing, perceived risk, testing process/procedures/effects, risk management, and results. These factors limited individuals' ability to make informed health care and treatment decisions. The most common barriers in the studies reviewed were related to social and community context (psychosocial), health care system, and education (cognitive), respectively.

Social and Community Context (psychosocial,)

The influence of social factors on an individual's belief or behavior were the most commonly cited barriers. Fourteen out of sixteen $(87 \%)$ of the articles cited social barriers. Family concerns $(50 \%)$ followed by fear or worry of positive breast cancer results $(43 \%)$, discrimination related to employment, healthcare system or denied health coverage due to pre-existing conditions (37\%), medical mistrust $(31 \%)$, and stigmatization due to breast cancer status $(31 \%)$ were the most common social barriers. Other barriers included lack of privacy $(18 \%)$, shame of being a burden to society $(12 \%)$, fatalism, powerless to control the onset and progression of cancer (12\%), nonscientific beliefs (6\%), and disinterest (6\%).

\section{Healthcare System}

The healthcare system barriers focused on health care coverage, provider knowledge, and access to quality or specialized services including community counseling services. Health care coverage was the most cited health care barrier. Ten out of sixteen (62\%) of the articles cited financial concerns regarding lack of insurance coverage or out of pocket costs. Provider barriers focused on lack of referrals (31\%), lack of effective referral system to track AAW's referral progress $(6 \%)$, lack of knowledge of genetic services $(6 \%)$, lack of genetic testing with clinical guidelines for cancer susceptibility $(6 \%)$, and limited time to counsel $(6 \%)$. Other health care concerns included lack of access to quality or specialized services (6\%) and limited number of community counseling services $(6 \%)$.

\section{Education}

Lack of knowledge was the most cited health literacy barrier. Eight out of sixteen $(50 \%)$ of the articles cited lack of knowledge about perceived risks, genetic testing process/procedures, risk management results, side effects associated with genetic testing, and having difficulty making health care decisions about genetic testing and selecting treatment options as barriers. Only one article $(6 \%)$ cited language as a barrier.

\section{Economic Stability and Neighborhood and Built Environments}

Four out of sixteen articles (25\%) cited income related to constraints beyond an individual's ability to pay for services including work conflict (6\%) as a reason for failing to keep medical appointments. Only one (6\%) article cited lack of transportation as a barrier. 
Table 5 Barriers to genetic testing experienced by African American Women

\begin{tabular}{|c|c|c|c|c|}
\hline $\begin{array}{l}\text { Social } \\
\text { Determinants of } \\
\text { Health }\end{array}$ & Factors & Description & $\begin{array}{l}\text { Articles (\%) } \\
\quad \mathrm{N}=16\end{array}$ & References \\
\hline $\begin{array}{l}\text { Economic } \\
\text { stability }\end{array}$ & $\begin{array}{l}\text { Employment, } \\
\text { Income, medical } \\
\text { bills, support }\end{array}$ & $\begin{array}{l}\text { Constraints beyond individual's } \\
\text { ability to pay for services }\end{array}$ & $4(25 \%)$ & $\begin{array}{l}\text { Adams et al, }{ }^{29} \text { Hayden et al, }{ }^{33} \\
\text { Jones et al, }{ }^{13} \text { and Ramirez et } \\
\text { al }\end{array}$ \\
\hline Education & $\begin{array}{l}\text { Language Health } \\
\text { literacy/ Education } \\
\text { level }\end{array}$ & $\begin{array}{l}\text { Lack of knowledge: } \\
\text { Perceived risk, testing process, } \\
\text { procedures; risk-management, } \\
\text { results; decision making; side } \\
\text { effects associated with testing }\end{array}$ & $8(50 \%)$ & $\begin{array}{l}\text { Jones et al, }{ }^{11} \text { Adams et al, }{ }^{29} \\
\text { Sheppard et al, }{ }^{17} \text { Glenn et al, }{ }^{31} \\
\text { Klitzman }{ }^{34}, \text { Susswein et al, }{ }^{24} \\
\text { MacNew et al, }{ }^{35} \text { and Sherman } \\
\text { et al }{ }^{38}\end{array}$ \\
\hline $\begin{array}{l}\text { Social \& } \\
\text { community } \\
\text { context }\end{array}$ & $\begin{array}{l}\text { Social integration } \\
\text { Support systems } \\
\text { Sociocultural }\end{array}$ & $\begin{array}{l}\text { Discrimination: employment, } \\
\text { healthcare system, preexisting } \\
\text { condition, race } \\
\text { Stigmatization due to breast } \\
\text { cancer status } \\
\text { Family concerns: Ineffective } \\
\text { communication, lack of } \\
\text { awareness of family history, } \\
\text { medical condition and hereditary } \\
\text { effects, medical } \\
\text { Medical mistrust } \\
\text { Privacy concerns } \\
\text { Cancer fear/worry }\end{array}$ & $\begin{array}{l}5(31 \%) \\
5(31 \%) \\
8(50 \%)\end{array}$ & 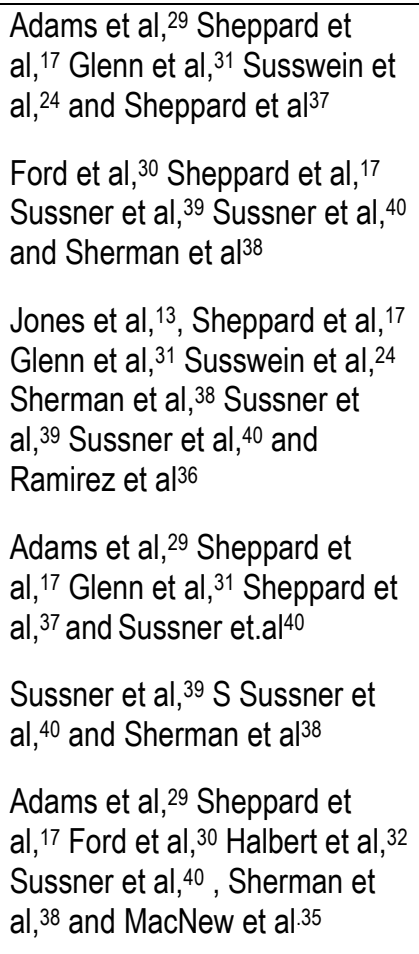 \\
\hline $\begin{array}{l}\text { Health care } \\
\text { system }\end{array}$ & $\begin{array}{l}\text { Provider access } \\
\text { Linguistic and } \\
\text { cultural } \\
\text { competency } \\
\text { Health care } \\
\text { coverage }\end{array}$ & $\begin{array}{l}\text { Providers: Lack of genetic } \\
\text { knowledge /services and clinical } \\
\text { guidelines for testing and } \\
\text { referrals, ineffective referral } \\
\text { system, limited counseling } \\
\text { Cost, lack of insurance coverage, } \\
\text { or out of pocket costs, inability to } \\
\text { qualify for hardship assistance }\end{array}$ & $10(62 \%)$ & $\begin{array}{l}\text { Jones et al, }{ }^{13} \text { Klitzman, }{ }^{34} \\
\text { Sheppard et al, }{ }^{37} \text { Sheppard et } \\
\text { al, }{ }^{17} \text { and Susswein et al24 } \\
\text { Jones et al, }{ }^{11} \text { Adams et al, }{ }^{29} \\
\text { Jones et al, }{ }^{13} \text { Sheppard et al, }{ }^{17} \\
\text { Glenn et al, }{ }^{31} \text { Ford et al, }{ }^{30} \\
\text { Susswein et al, }{ }^{24} \text { Sherman et } \\
\text { al, }{ }^{38} \text { Ramirez et al, }{ }^{36} \text { and } \\
\text { Hayden et all33 }\end{array}$ \\
\hline
\end{tabular}




\section{DISCUSSION}

Evidence from the review suggests the SDOH collectively, influences genetic follow up and how healthcare decision are made among AAW. Social contexts and community engagement, the healthcare system, and health literacy are identified as key problematic areas and warrant consideration.

\section{Social and Community Context}

Social and community context factors have the greatest influence on AAW's genetic testing follow up and how they make decisions. Family concerns have the greatest influence followed by fear/worry about cancer, discrimination related to employment, the healthcare system or healthcare coverage due to breast cancer status, medical mistrust, and stigmatization respectively. Family concerns were related to AAW's inability to discuss their breast cancer conditions because they do not fully understand their breast cancer conditions and how it impact their families. The main concerns are ineffective communication, lack of awareness of family history, effects of medical condition, and heredity.

The few published studies exploring medical mistrust demonstrated significant associations with perceived advantages and disadvantages of genetic testing, as well as medical mistrust among African Americans. The findings revealed how social and cultural beliefs foster AAW's misunderstandings about genetic testing elicit medical mistrust, an important predictor of health behaviors in AAW. The most common reasons for medical mistrust are fear that medical institutions would use genetic test results exclusively for beneficial reasons, privacy concerns, and loss of medical coverage or employment if their breast cancer status is identified. These beliefs are closely associated with employment, the healthcare system, or healthcare coverage discrimination. The misunderstandings highlight the need to dispel myths about breast cancer genetic testing.

\section{Spiritual/religious Beliefs}

Several studies (25\%) explored AAW's spiritual/religious cultural beliefs to some degree. Overall, AAW's attitudes about breast cancer and genetic testing, are associated with their spiritual/religious beliefs. One study suggests the use of spiritual coping has been associated with a perception of lower breast cancer risk. ${ }^{21}$ More work is needed in this area to fully understand spirituality/religious effects.

\section{Community Engagement}

Approaches to address breast cancer health inequality should be addressed at both the individual and community levels. A Community Partnership Program with local organizations to work in medically African American communities may promote targeted breast cancer prevention strategies, increase breast cancer genetic testing awareness, and reduce outcome disparities. Furthermore, the partnership may provide increased sponsorship and support to apply tailored strategies and resources to increase African Americans' community engagement.

\section{The Healthcare System}

In the healthcare system, insurance coverage and out of pocket costs continue to be primary barriers to genetic testing, followed by lack of provider genetic knowledge for AAW at risk for breast cancer and ineffective referral tracking systems. The existing data suggests the cost concerns expressed by the AAW are associated with their socioeconomic status. African Americans have the lowest median household income among White, Asian and Latino households in the U.S. ${ }^{22}$ Although the median household income rose to $\$ 57,617$ in 2016 , for African Americans, it was $\$ 38,555$, the lowest of all racial groups. ${ }^{22}$ Moreover, $22 \%$ of African American households live in poverty, and African Americans' unemployment rate almost doubles the rate of Whites. ${ }^{22}$ One study showed affordability and insurance coverage as key reasons for non-genetic test follow up. ${ }^{23}$

Seeking additional funding opportunities such as community partnership may mitigate costs. Currently, public policies such as the Affordable Care Act, provide access to healthcare services for genetic screening and preventative services for high risk women. Community partnerships with health insurance agencies and health care organizations to lower health care costs may increase AAW's access to genetic screening and treatment. Nonetheless, factors influencing AAW's access to care should continue to be examined to discover the association between cost and other sociocultural factors. One study showed that African Americans were less likely than Whites to pursue BRCA1/2 genetic testing, even when barriers of cost and access were minimized. ${ }^{24}$

\section{Referral System}

Some high risk AAW who are eligible for genetic testing are not referred; this contributed to a paucity of provider referrals and inadequate referral tracking systems to track the progression from initial identification and referral for genetic counseling/testing to genetic specialists and oncologists. One study revealed 5 of 11 women with a history of bilateral breast cancer and carry a BRCA $V$ 2 mutation were not referred for risk assessment at the time of diagnosis, and could have been recommended to reduce the risk 
of developing a second breast cancer. ${ }^{25}$ More efforts are needed to address this issue because AAW are predisposed to a more aggressive form of breast cancer at an earlier age than the general population.

\section{Provider Training}

African American women have high trust in their personal providers and their recommendations for genetic testing. Other studies produced similar findings. ${ }^{26,27}$ Yet, existing evidence suggests providers may not be culturally competent enough to address AAW's psychosocial needs, including the need for genetic and specialized services. Cultural competency is key to comprehending how AAW's attitudes and beliefs, impact their health, and consequently, improve patient-provider relations. The majority of genetic services providers $(91 \%)$ and counselors in the U.S., are White, from a different ethnic group and may not understand AAW's needs. ${ }^{25}$

One study surveyed 220 internists about their genetic utilizations; findings showed most rated their knowledge as very/somewhat poor concerning geneticists/genetic counselors, types of tests to order, counseling patients, interpreting results and maintaining privacy. ${ }^{28}$ Providers may not know how to identify and treat high risk patients or make appropriate referrals. Several studies suggest physicians with poorer understanding of breast cancer genetics recommend genetic services less frequently. ${ }^{25}$ Increasing culturally competent, knowledgeable providers may improve patient-provider relationships, build trust and provide AAW with the information to make informed, valued decisions.

\section{Health Literacy/Education}

Fifty percent of the studies identified culturally tailored education for AAW and their families as key to increasing genetic breast cancer awareness and early detection, mitigating misconceptions about genetic testing, improving informed valued decisions about genetic testing and treatment options, and improving clinical outcomes. Recurring themes focused on helping AAW understand the advantages and disadvantages to genetic testing, how to make use of the genetic test results for themselves and their families, how breast cancer impacts their health behaviors and lifestyle choices, and how to reduce their risk of dying from breast cancer. Furthermore, evidence suggests that forums to discuss the roles of spiritual and religious values, beliefs and attitudes, and family or friends influence on the decision-making process may improve the accuracy of their risk perceptions.

\section{RECOMMENDATIONS}

The existing evidence suggests a multi-faceted approach should be taken to address the multidimensional nature of breast cancer disparity among AAW. Their families are key motivators to genetic follow up and should be included. Furthermore, AAW make decisions based on family values, and genetic follow up is associated with understanding more about their families' breast cancer risk. A comprehensive, tailored genetic breast cancer education and outreach screening intervention is needed, as African Americans and other minorities trail behind in the utilization of genetic services to reduce breast cancer mortality rates, improve survival rates, and health and quality of life. Table 6 summarizes the recommendations. Three major categories of recommendations in the reviewed studies are relevant to addressing barriers to genetic follow up and treatment. These categories are associated with the SDOH and include biologic and psychosocial topics related to health literacy, social and community context, and the healthcare system. They should be considered when developing tailored breast cancer risk program content for AAW.

\section{LIMITATIONS}

This review has several limitations. The review explores barriers and why AAW do not progress to genetic testing. As a result, most of the studies are descriptive and cross-sectional in nature and do not allow for determination of cause and effect relationships in the observed associations. Other limitations include self-reported data regarding the use of genetic services, some samples are not reflective of AAW with less education or low income, some studies have small sample sizes, some underrepresent younger AAW, and others are limited to those published in the U.S. Furthermore, there is limited experimental data on why AAW do not progress to genetic testing, and some results are not generalizable to other populations. Despite these limitations, the results are meaningful. Studies included a diverse set of AAW from different regions of the U.S. but still produced similar findings. 
Table 6. Recommendations for Designing Tailored Breast Cancer Risk Programs for African American Women (AAW)

\begin{tabular}{|c|c|}
\hline Category & Description \\
\hline Education & $\begin{array}{l}\text { Rationale: Improve patient-provider relationship. Develop culturally competent providers and increase their } \\
\text { genetic utilization and increase African American women's breast cancer genetic } \\
\text { awareness. } 11,13,23,27,29-31,36,39 \\
\text { Primary care provider training } \\
\text { Cultural competency (include unique cultural beliefs of minorities) } \\
\text { Exploration of unconscious biases } \\
\text { Identification of breast cancer support services and how to refer } \\
\text { Utilization of breast cancer genetic testing clinical guidelines, include ordering and interpreting genetic } \\
\text { results and genetic privacy } \\
\text { Utilization of a standardized risk assessment tool } \\
\text { African American women and family education } \\
\text { Breast cancer awareness } \\
\text { Family history } \\
\text { Breast cancer genetics: counseling/testing: process/procedure, benefits, advantages and } \\
\text { disadvantages, risks, reliability of test results } \\
\text { Medication side effects } \\
\text { Psychosocial exploration: trust related to data usage, breast cancer worry/fear } \\
\text { Stigmatization and perceptions } \\
\text { Cultural exploration of spiritual and religious values, decision-making with decision-making aids } \\
\text { Genetic Information Nondiscrimination Act law to dissipate fear of discrimination. }\end{array}$ \\
\hline $\begin{array}{l}\text { Healthcare } \\
\text { System }\end{array}$ & $\begin{array}{l}\text { Rationale: Improve access to quality or specialized services to increase early detection, diagnosis and } \\
\text { treatment.11,13,17,23,24,29-31,33,36,38 } \\
\text { Establish an effective referral tracking system to track progress: } \\
\text { Utilization of electronic record system } \\
\text { Standardized family history data collection forms to identify high risk individuals } \\
\text { Available genetic services within settings that provide healthcare services to large } \\
\text { numbers of AAW } \\
\text { Risk assessment } \\
\text { Conduct breast cancer risk assessment screening during annual,/primary care or } \\
\text { gynecologic visits } \\
\text { Target younger AAW at increased risk for breast cancer } \\
\text { Explore opportunities to increase health care coverage and reimbursement }\end{array}$ \\
\hline $\begin{array}{l}\text { Social \& } \\
\text { Community } \\
\text { Context }\end{array}$ & $\begin{array}{l}\text { Rationale: Promote community engagement to increase access to effective care and treatment. }{ }^{24,29,37,38} \\
\text { Establish community level breast cancer education and risk assessment } \\
\text { Support outreach efforts to groups that provide information and support to younger breast cancer victims } \\
\text { Identify places within the communities with flexible counseling hours }\end{array}$ \\
\hline
\end{tabular}




\section{IMPLICATIONS FOR PRACTICE AND/OR POLICY}

These findings have decisive implications for medical practice, education, community leaders, and policy makers. Although AAW who are at increased risk may report positive interests about genetic testing, few elect to follow-up with genetic testing. The limited number of studies that have evaluated genetic test acceptance in this population, suggest that barriers to participation in genetic counseling/testing, continues to exist. Furthermore, few interventions have been designed to fully address the multifaceted nature of AAW who are at high risk for breast cancer nor developed comprehensive interventions that address the influence of multiple $\mathrm{SDOH}$ that present as barriers for many minority women. Many of the barriers that are addressed in this review are the unresolved barriers that existed over 15 years ago, indicating the need to develop educational interventions as adjuncts to genetic screening/testing and increase access to effective care and community engagement.

The results of this review could be used to design comprehensive, tailored interventions to address the identified barriers, increase breast cancer awareness and early detection, and help minority women make informed, value decisions about genetic testing and treatment options. Given the breast cancer impact on women, as well as nationally and premature deaths rates, efforts should continue to increase access to effective care and treatment, especially in underserved communities.

Future studies are needed to examine methods to increase community engagement and its impact on breast cancer awareness and decreasing the mortality rate; assess provider education for those who do not specialize in breast cancer; examine how race and cultural identity influence beliefs about genetic testing, explore emotional and psychosocial factors related to genetic follow up, and identify factors influencing the decision-making process. We recommend using larger sample sizes reflective of a diverse African American population and include more AAW who are younger and at high risk, have low income and education level, and are uninsured/underinsured.

\section{CONCLUSIONS}

This systematic review is one of the few reviews to synthesize current published literature focused on the social determinants of health (SDOH) factors collectively, influencing breast cancer genetic follow up from the perspective of AAW who are at risk for breast cancer, to determine why they do not progress to genetic testing. It provides greater understanding of how SDOH, especially cultural beliefs and attitudes about breast cancer, influence decisions about genetic testing and treatment. Furthermore, the review includes recommendations for designing tailored breast cancer risk programs for AAW to reduce breast cancer disparity. The review highlights the need to accurately assess AAW's perceptions about breast cancer and their progression to genetic services.

\section{REFERENCES}

1. American Cancer Society. Cancer facts \& figures 2017. Atlanta, GA: American Cancer Society; 2017.

2. American Cancer Society. Cancer prevention \& early detection facts \& figures for 2017-2018. Atlanta, GA: American Cancer Society; 2017.

3. Center for Disease Control and Prevention Web Site. Cancer among women. Available at: https://www.cdc.gov/cancer/dcpc/data/women.htm. Published 2016. Updated June 5, 2017. Accessed February 27, 2018.

4. National Institute of Health. National Cancer Institute Web Site. Cancer health disparities. Available at: https://www.cancer.gov/about-nci/organization/crchd/cancer-health-disparities-fact-sheet. Updated March 11, 2008. Accessed February 27, 2018.

5. Katapodi MC, Northouse LL, Milliron KM, Liu G, Merajver SD. Individual and family characteristics associated with BRCA1/2 genetic testing in high-risk families. Psychooncology. 2013;22:1336-1343. doi: 10.1002/pon.3139 [PMID: 22826208]

6. Institute of Medicine. How far have we come in reducing health disparities? Progress since 2000: Workshop summary. Washington, DC: The National Academies Press; 2012.

7. Johnson $\mathrm{K}$. Breast cancer gene mutations more common in black women. Available at: http://www.medscape.com/viewarticle/805431. Annual Meeting of the American Society of Clinical Oncology: Abstract 1501. Presented June 3, 2013; Chicago, IL. Accessed September 25, 2017.

8. American Cancer Society. Cancer facts \& figures for African Americans 2016-2018. Atlanta, GA: American Cancer Society; 2016.

9. Keenan T, Moy B, Mroz EA, Ross K, Niemierko A, Rocco JW, Isakoff S, Ellisen LW, Bardia A. Comparison of the genomic landscape between primary breast cancer in African American versus White women and the association of racial differences with tumor recurrence. J Clin. Oncol. 2015;33(31):3621-3628. [PMID: 26371147]

10. Kurian AW, Griffith K, Hamilton AS, Ward KC, Morrow M, Katz SJ, Jagsi R. Genetic testing and counseling among patients with newly diagnosed breast cancer. JAMA. 2017;317(5):531-534. [PMID: 28170472]

11. Jones TP, Katapodi MC, Lockhart JS. Factors influencing breast cancer screening and risk assessment among young African American women: An integrative review of the literature. J. Am. Assoc. Nurse Pract. 2015;27:521-529. [PMID: 
25736320]

12. Menes TS, Terry MB, Goldgar D, Andrulis IL, Knight JA, John EM, Liao Y, Southey M, Miron A, Chung W, Buys SS. Second primary breast cancer in BRCA1 and BRCA2 mutation carriers: 10-year cumulative incidence in the Breast Cancer Family Registry. Breast Cancer Res Treat. 2015;151(3):653-660. [PMID: 25975955]

13. Jones T, Lockhart JS, Mendelsohn-Victor KE, Duquette D, Northouse LL, Duffy SA, Donley R, Merajver SD, Milliron K J, Roberts S, Katapodi MC. Use of cancer genetics services in African-American young breast cancer survivors. Am J Prev Med. 2016;51(4):427-436. [PMID: 27117712]

14. Braveman P, Gottlieb L. The social determinants of health: It's time to consider the causes of the causes. Public Health Rep. 2014;129(Suppl. 2):19-31. [PMID: 24385661]

15. Noonan AS, Velasco-Mondragon HE, Wagner FA. Improving the health of African Americans in the USA: An overdue opportunity for social justice. Public Health Rev. 2016);37(12):1-20. doi: 10.1186/s40985-016-0025-4. [PMID: 29450054]

16. Churpek J. Inherited mutations in susceptibility genes are common in younger African American women with breast cancer. Available at: http://www.uchospitals.edu/news/2013/20130603-breast-cancer.html. Published 2013. Accessed July 17, 2017.

17. Sheppard VB, Graves K D, Christopher J, Hurtado-de-Mendoza A, Talley C, Williams KP. African American women's limited knowledge and experiences with genetic counseling for hereditary breast cancer. J Genet Couns. 2014;23(3):311-322. [PMID: 24186304]

18. Frosch DL, Légaré F, Fishbein M, Elwyn G. Adjuncts or adversaries to shared decision-making? Applying the integrative model of behavior to the role and design of decision support interventions in healthcare interactions. Implement Sci. 2009;4(73):1-10. doi:10.1186/1748-5908-4-73. [PMID: 19909547]

19. The Joanna Briggs Institute Levels of Evidence and Grades of Recommendation Working Party*. Summary of Findings Tables for Joanna Briggs Institute Systematic Reviews. The Joanna Briggs Institute joannabriggs.org 2014.

20. The PRISMA Statement. PLoS Med 6(7): e1000097. doi:10.1371/journal.pmed1000097.

21. Ma AM, Barone J, Wallis AE, Wu NJ, Garcia LB, Estabrook A, Rosenbaum-Smith SM, Tartter PI. Noncompliance with adjuvant radiation, chemotherapy, or hormonal therapy in breast cancer patients. Am J Surg. 2008;196:500-504. [PMID: 18809051]

22. U.S. Census Bureau. Website. Mean income in the past 12 months (in 2016 inflation-adjusted dollars). Available at http://factfinder2.census.gov/. Accessed February 27, 2018.

23. Kieran S, Loescher L J, Lim K H. The role of financial factors in acceptance of clinical BRCA genetic testing. Genet Test. 2007;11(1):101-110. [PMID: 17394399]

24. Susswein LR, Skrzynia C, Lange LA, Booker JK, Graham III ML, Evans JP. Increased uptake of BRCA1/2 genetic testing among African American Women with a recent diagnosis of breast cancer. J Clin Oncol. 2008;26(1):32-36. [PMID: 18165638]

25. Forman $A D$, Hall MJ. Influence of race/ethnicity on genetic counseling and testing for hereditary breast and ovarian cancer. Breast J. 2009;15(Suppl. 1):56-62.[ PMID: 19775331]

26. Armstrong K, Micco E, Carney A, Stopfer J, Putt M. Racial differences in the use of BRCA1/2 testing among women with a family history of breast or ovarian cancer. JAMA. 2005;293(14):1729-1736. [PMID: 15827311]

27. Pal T, Cragun D, Lewis C, Doty A, Rodriguez M, Radford C, Thompson C, Kim J, Vadaparampil ST. Statewide survey of practitioners to assess knowledge and clinical practices regarding hereditary breast and ovarian cancer. Genet Test Mol Biomarkers. 2013;7(5):367-375. [PMID: 23448386]

28. Klitzman R, Chung W, Marder K, Shanmugham A, Chin L J, Stark M, Leu C-S, Appelbaum PS. Attitudes and practices among internists concerning genetic testing. J Genet Couns. 2013;22(1):90-100. doi:10.1007/s10897-012-9504-z. [PMID: 22585186]

29. Adams I, Christopher J, Williams KP, Sheppard VP. (2015). What Black women know and want to know about counseling and testing for BRCA1/2. J Cancer Educ;30(2):344-352. [PMID: 25301325]

30. Ford ME, Alford SH, Britton D, McClary B, Gordon HS. Factors influencing perceptions of breast cancer genetic counseling among women in an urban health care system. J Genet Couns. (2007);16(6):735-53. [PMID: 17701328]

31. Glenn BA, Chawla N, Bastani R. Barriers to genetic testing for breast cancer risk among ethnic minority women: An exploratory study. Ethn Dis. 2012;22:267-273. [PMID: 22870568]

32. Halbert CH, Kessler L, Troxel AB, Stopfer J.E, Domchek S. Effect of genetic counseling and testing for BRCA1 and BRCA2 mutations in African American women: A randomized trial. Public Health Genomics. 2010;13:440-448. doi: 10.1159/000293990. [PMID: 20234119]

33. Hayden S, Mange S, Duquette D, Petrucelli N, Raymond VM. \& on behalf of the BRCA Clinical Network Partners. Large prospective analysis of the reasons patients do not pursue BRCA genetic testing following genetic counseling. $J$ Genet Couns. 2017. 26:859-865. doi:10.1007/s10897-016-0064-5. [PMID: 28093663]

34. Klitzman RL. Misunderstandings concerning genetics among patient confronting genetic disease. J Genet Couns. 
2010;19:430-446. [PMID: 20512408]

35. MacNew HG, Rudolph R, Brower ST, Beck AN, Meister EA. Assessing the knowledge and attitudes regarding genetic testing for breast cancer risk in our region of southeastern Georgia. Breast J. 2010;16(2):189-92. [PMID: 20030654]

36. Ramirez AG, Chalela P, Gallion K.J, Muñoz E, Holden AE, Burhansstipanov L, Smith SA, Wong-Kim ., Wyatt SW, \& Suarez L. Attitudes toward breast cancer genetic testing in five special population groups. J Health Dispar Res Pract. 2015;8(4):124-135. [PMID: 26855846]

37. Sheppard VB, Mays D, LaVeist L, Tercyak KP. Medical mistrust influences black women's level of engagement in BRCA1/2 genetic counseling and testing. JAMA. 2013;105:17-22. [PMID: 23862292]

38. Sherman K A, Miller, SM, Shaw L-K, Cavanagh K, Sheinfeld-Gorin S. (2014). Psychosocial approaches to participation in BRCA1/2 genetic risk assessment among African American women: A systematic review. J Community Genet;5:89-98. doi 10.1007/s12687-013-0164-y. [PMID: 23934762]

39. Sussner KM, Thompson HS, Jandor L, Edwards TA, Forman A, Brown K, Kapil- Pair N, Bovbjerg DH, Schwartz MD, Valdimarsdottir HB. The influence of acculturation and breast cancer-specific distress on perceived barriers to genetic testing for breast cancer among women of African descent. Psychooncology. 2009;18:945-955. [PMID: 19090507]

40. Sussner KM, Edwards TA, Thompson HS, Jandorf L, Kwate NO, Forman A, Brown K, Kapil-Pair N, Bovbjerg DH, Schwartz $\mathrm{MD}$, Valdimarsdotti, $\mathrm{HD}$. Ethnic, racial, and cultural identity and perceived benefits and barriers related to genetic testing for breast cancer among at-risk women of African Descent in New York City. Public Health Genomics. 2011;14:356-370. doi: 10.1159/000325263. [PMID: 21540561] 


\section{Appendix A}

Table 4. Study Characteristics and Summary of Key Findings of Factors Influencing Genetic Uptake (Appendix A, 1/3)

\begin{tabular}{|c|c|c|c|c|c|c|c|c|}
\hline $\begin{array}{l}\text { Author, } \\
\text { Year }\end{array}$ & Design & $\begin{array}{l}\text { Sample } \\
\text { Size }\end{array}$ & $\begin{array}{l}\text { Sample Population } \\
\text { (U.S. region, age) }\end{array}$ & Focus & Measures & Key Findings & $\begin{array}{l}\text { Grade } \\
\text { Quality }\end{array}$ & $\begin{array}{l}\text { Recommended } \\
\text { Grade }\end{array}$ \\
\hline $\begin{array}{l}\text { Adams } \\
\text { et al } 29\end{array}$ & $\begin{array}{l}\text { Cross- } \\
\text { sectional }\end{array}$ & $N=50$ & East, AAW, $\geq 21$ & $\begin{array}{l}\text { Assessed } \\
\text { knowledge and } \\
\text { perception of GC for } \\
\text { BRCA1/2 }\end{array}$ & $\begin{array}{l}\text { Knowledge, } \\
\text { motivator, barrier } \\
\text { and interest }\end{array}$ & $\begin{array}{l}88 \% \text { never heard of BRCA } 1 / 2,54 \% \\
\text { aware of GT, } 94 \% \text { GT interest } \\
\text { Motivators: physician } \\
\text { recommendation, health awareness } \\
\text { and family history }\end{array}$ & 3 & A \\
\hline $\begin{array}{l}\text { Ford et } \\
\text { al }\end{array}$ & $\begin{array}{l}\text { Focus } \\
\text { groups }\end{array}$ & $N=20$ & Midwest, AAW, WW & $\begin{array}{l}\text { Explored } \\
\text { knowledge, } \\
\text { attitudes and } \\
\text { cultural beliefs of } \\
\text { breast cancer }\end{array}$ & $\begin{array}{l}\text { Socio- } \\
\text { demographics, } \\
\text { cognitive } \\
\text { /psychological, } \\
\text { social support and } \\
\text { programmatic } \\
\text { factors }\end{array}$ & $\begin{array}{l}\text { All groups associated "breast cancer" } \\
\text { with fear; } \\
\text { AAW who did not receive GC were } \\
\text { most knowledgeable; WW who did not } \\
\text { receive GC; reported uncertainty and } \\
\text { mistrust about GC/GT }\end{array}$ & 3 & $\begin{array}{l}\text { B } \\
\text { Unclear } \\
\text { management } \\
\text { strategy }\end{array}$ \\
\hline $\begin{array}{l}\text { Glenn et } \\
\text { al } 31\end{array}$ & $\begin{array}{l}\text { Semi- } \\
\text { structural } \\
\text { interviews }\end{array}$ & $N=33$ & $\begin{array}{l}\text { West, White, Asian, } \\
\text { Latino and African } \\
\text { American survivors or } \\
\text { first-degree relatives of } \\
\text { survivors, mean age } \\
52\end{array}$ & $\begin{array}{l}\text { Assessed GC/GT } \\
\text { awareness and } \\
\text { factors influencing } \\
\text { GT follow-up }\end{array}$ & $\begin{array}{l}\text { Factors influencing } \\
\text { genetic follow-up }\end{array}$ & $\begin{array}{l}\text { Low levels of awareness observed in } \\
\text { minority women, beliefs influenced } \\
\text { decisions about treatment options, } \\
\text { mistrust of genetic information. }\end{array}$ & 3 & $A$ \\
\hline $\begin{array}{l}\text { Halbert } \\
\text { et al } 32\end{array}$ & $\begin{array}{l}\text { Randomized } \\
\text { trial, } \\
\text { longitudinal }\end{array}$ & $\mathrm{N}=176$ & East, AAW, adults & $\begin{array}{l}\text { Evaluated the } \\
\text { effects of GC/GT } \\
\text { based on different } \\
\text { levels of exposure }\end{array}$ & $\begin{array}{l}\text { Evaluated cancer } \\
\text { perceived risk and } \\
\text { cancer worry }\end{array}$ & $\begin{array}{l}\text { Counseling participants reported } \\
\text { perceived risk compared to non- } \\
\text { participants, test result acceptors } \\
\text { reported decreases in cancer worry, } \\
\text { having a cancer history associated } \\
\text { with increases in cancer worry }\end{array}$ & 2 & $A$ \\
\hline $\begin{array}{l}\text { Hayden } \\
\text { et al }{ }^{33}\end{array}$ & $\begin{array}{l}\text { Prospective } \\
\text { analysis, } \\
\text { longitudinal }\end{array}$ & $\begin{array}{l}N= \\
10,726\end{array}$ & $\begin{array}{l}\text { Midwest, Asian, } \\
\text { African American and } \\
\text { White adults }\end{array}$ & $\begin{array}{l}\text { Analyzed reasons } \\
\text { GT not pursue after } \\
\text { GC }\end{array}$ & $\begin{array}{l}\text { Socio- } \\
\text { demographic, GT } \\
\text { patterns and } \\
\text { barriers to GT }\end{array}$ & $\begin{array}{l}\text { 51.4\% did not pursue GT following } \\
\text { GC-not indicated, } 22.5 \% \text {-cost } \\
\text { concerns, } 17.1 \% \text {-disinterest }\end{array}$ & 3 & $A$ \\
\hline
\end{tabular}

Key: AAW, African American Women; WW, White Women; GC, Genetic counseling; GT, Genetic testing 
Table 4. Study characteristics and key findings of factors influencing genetic uptake (Appendix A, 2/3)

\begin{tabular}{|c|c|c|c|c|c|c|c|c|}
\hline $\begin{array}{l}\text { Author, } \\
\text { Year }\end{array}$ & Design & $\begin{array}{l}\text { Sample } \\
\text { Size }\end{array}$ & $\begin{array}{l}\text { Sample Population } \\
\text { (U.S. region, age) }\end{array}$ & Focus & Measures & Key Findings & $\begin{array}{l}\text { Grade } \\
\text { Quality }\end{array}$ & $\begin{array}{l}\text { Recommended } \\
\text { Grade }\end{array}$ \\
\hline $\begin{array}{l}\text { Jones et } \\
\text { al11 }\end{array}$ & $\begin{array}{l}\text { Descriptive } \\
\text { critical review }\end{array}$ & $N=23$ & $\begin{array}{l}\text { General population of } \\
\text { AAW at increased } \\
\text { risk, }<50\end{array}$ & $\begin{array}{l}\text { Examined factors } \\
\text { influencing } \\
\text { screening }\end{array}$ & $\begin{array}{l}\text { factors influencing } \\
\text { need for health } \\
\text { services }\end{array}$ & $\begin{array}{l}\text { Younger AAW are not referred for } \\
\text { GT when appropriate and } \\
\text { make decisions based on family } \\
\text { values }\end{array}$ & 3 & $A$ \\
\hline $\begin{array}{l}\text { Jones et } \\
\text { al13 }^{13}\end{array}$ & $\begin{array}{l}\text { Prospective } \\
\text { RCT }\end{array}$ & $N=340$ & $\begin{array}{l}\text { Midwest, } A A \\
\text { survivors, } \\
\text { age } 20-45\end{array}$ & $\begin{array}{l}\text { Examined factors } \\
\text { associated with } \\
\text { GC/GT }\end{array}$ & $\begin{array}{l}\text { Knowledge/attitude, } \\
\text { subjective norms, } \\
\text { family support and } \\
\text { perceived control }\end{array}$ & $\begin{array}{l}\text { Significantly, less AAW-reported } \\
\text { having GC and GT } \\
\text { compared with WW/others, } \\
\text { Income associated positively with } \\
\text { GC/GT } \\
\text { Higher education levels } \\
\text { negatively associated with GC }\end{array}$ & 3 & A \\
\hline Klitzman 34 & $\begin{array}{l}\text { Semi- } \\
\text { structured } \\
\text { interview }\end{array}$ & $N=32$ & $\begin{array}{l}\text { AAs, Whites, Asians, } \\
\text { Hispanics with breast } \\
\text { cancer, age 20-69 }\end{array}$ & $\begin{array}{l}\text { Explored } \\
\text { misunderstandings } \\
\text { about GT }\end{array}$ & $\begin{array}{l}\text { Factors influencing } \\
\text { GT }\end{array}$ & $\begin{array}{l}\text { Most common-lack of } \\
\text { understanding about GT }\end{array}$ & 3 & $\begin{array}{l}\text { B groups' data } \\
\text { are not } \\
\text { partitioned } \\
\text { according to } \\
\text { condition }\end{array}$ \\
\hline $\begin{array}{l}\text { MacNew et } \\
\text { al } 35\end{array}$ & $\begin{array}{l}\text { Descriptive } \\
\text { survey }\end{array}$ & $\mathrm{N}=222$ & $\begin{array}{l}\text { Southeast, AA, White } \\
\text { and Hispanic women, } \\
\text { adults }\end{array}$ & $\begin{array}{l}\text { Assessed socio- } \\
\text { demographics, GT } \\
\text { awareness }\end{array}$ & $\begin{array}{l}\text { Socio-demographics, } \\
\text { knowledge and } \\
\text { attitude }\end{array}$ & $\begin{array}{l}\text { Women with advanced degrees } \\
\text { are most informed about BRCA } \\
\text { GT, More WW knew about breast } \\
\text { cancer genetics than other groups }\end{array}$ & 4 & $\mathrm{~A}$ \\
\hline $\begin{array}{l}\text { Ramirez et } \\
\text { al } 36\end{array}$ & $\begin{array}{l}\text { Cross- } \\
\text { sectional }\end{array}$ & $\mathrm{N}=49$ & $\begin{array}{l}\text { General population } \\
\text { AA, White, } \\
\text { Appalachian, Native } \\
\text { American, Asian } \\
\text { American, women, } \\
\text { age } 25-49\end{array}$ & $\begin{array}{l}\text { Evaluated ethnic } \\
\text { differences in } \\
\text { breast cancer } \\
\text { knowledge, belief } \\
\text { and GT follow-up }\end{array}$ & $\begin{array}{l}\text { Socio-demographics, } \\
\text { knowledge, attitude, } \\
\text { self-efficacy and } \\
\text { cultural } \\
\text { characteristics }\end{array}$ & $\begin{array}{l}\text { High GT interest } \\
\text { Significant cultural differences } \\
\text { associated with benefit and risk, } \\
\text { providers' recommendations, } \\
\text { medical mistrust, family effects, } \\
\text { and cost }\end{array}$ & 4 & $A$ \\
\hline $\begin{array}{l}\text { Sheppard } \\
\text { et al } 37\end{array}$ & $\begin{array}{l}\text { Cross- } \\
\text { sectional }\end{array}$ & $N=100$ & $\begin{array}{l}\text { Mid-Atlantic AAW at } \\
\text { increased risk for } \\
\text { carrying BRCA1/2 }\end{array}$ & $\begin{array}{l}\text { Examined } \\
\text { sociocultural } \\
\text { factors associated } \\
\text { with medical } \\
\text { mistrust and } \\
\text { genetic } \\
\text { discrimination } \\
\end{array}$ & $\begin{array}{l}\text { Socio-demographics, } \\
\text { mistrust, self-efficacy, } \\
\text { discrimination and } \\
\text { engagement }\end{array}$ & $\begin{array}{l}\text { Reported interest in GC/GT does } \\
\text { not translate into actual GC/GT } \\
\text { engagement } \\
43 \% \text { were not referred for GC/GT }\end{array}$ & 4 & $A$ \\
\hline
\end{tabular}


Table 4. Study characteristics and key findings of factors influencing genetic uptake (Appendix A, 3/3)

\begin{tabular}{|c|c|c|c|c|c|c|c|c|}
\hline $\begin{array}{l}\text { Author, } \\
\text { Year }\end{array}$ & Design & $\begin{array}{l}\text { Sample } \\
\text { Size }\end{array}$ & $\begin{array}{l}\text { Sample Population } \\
\text { (U.S. region, age) }\end{array}$ & Focus & Measures & Key Findings & $\begin{array}{l}\text { Grade } \\
\text { Quality }\end{array}$ & $\begin{array}{l}\text { Recommended } \\
\text { Grade }\end{array}$ \\
\hline $\begin{array}{l}\text { Sheppard } \\
\text { et al17 }\end{array}$ & $\begin{array}{l}\text { Semi- } \\
\text { structured } \\
\text { interviews }\end{array}$ & $N=21$ & $\begin{array}{l}\text { East, AA adults at } \\
\text { risk for hereditary } \\
\text { breast cancer }\end{array}$ & $\begin{array}{l}\text { Explored barriers and } \\
\text { motivators to genetic } \\
\text { follow-up }\end{array}$ & $\begin{array}{l}\text { Knowledge, } \\
\text { beliefs and } \\
\text { attitudes about } \\
\text { GC/GT }\end{array}$ & $\begin{array}{l}\text { Low knowledge level about GC } \\
\text { and BRCA } 1 / 2 \text {, spiritual beliefs } \\
\text { were described as a potential } \\
\text { source of hope and coping, } \\
\text { Motivators: help family members, } \\
\text { insurance coverage, and benefit } \\
\text { community }\end{array}$ & 4 & A \\
\hline $\begin{array}{l}\text { Sherman } \\
\text { et al }{ }^{38}\end{array}$ & $\begin{array}{l}\text { Systematic } \\
\text { Review }\end{array}$ & $N=18$ & $\begin{array}{l}\text { General population } \\
\text { of AAW who } \\
\text { participated in } \\
\text { GC/GT }\end{array}$ & $\begin{array}{l}\text { Reviews included factors } \\
\text { influencing GT follow-up } \\
\text { and decision making. }\end{array}$ & $\begin{array}{l}\text { Knowledge, } \\
\text { perceived risk, } \\
\text { beliefs, and } \\
\text { emotional factors } \\
\text { influencing } \\
\text { GC/GT uptake }\end{array}$ & $\begin{array}{l}\text { AAW reported interest in GC/GT } \\
\text { does not translate into actual } \\
\text { GC/GT engagement, low GT } \\
\text { knowledge level, } \\
\text { spirituality associated with } \\
\text { increased uptake, pretest } \\
\text { counseling reduced cancer worry } \\
\text { and greater decision satisfaction, } \\
\text { GC that incorporates beliefs, } \\
\text { reported less worries }\end{array}$ & 1 & A \\
\hline $\begin{array}{l}\text { Sussner } \\
\text { et al } 40\end{array}$ & $\begin{array}{l}\text { Cross- } \\
\text { sectional }\end{array}$ & $N=160$ & $\begin{array}{l}\text { East, AA, } \\
\text { Black-West Indian/ } \\
\text { Caribbean and } \\
\text { Black-Other women } \\
\text { at increased risk for } \\
\text { hereditary breast- } \\
\text { ovarian cancer }\end{array}$ & $\begin{array}{l}\text { Explored ethnic, racial, } \\
\text { and cultural identity } \\
\text { factors associated with GT } \\
\text { follow-up }\end{array}$ & $\begin{array}{l}\text { Ethnic, racial, and } \\
\text { cultural identity } \\
\text { predictors }\end{array}$ & $\begin{array}{l}\text { Strong sense of ethnic identity } \\
\text { related to having more positive } \\
\text { beliefs and attitudes about GT, } \\
\text { high ethnic search and racial } \\
\text { identity scores associated with } \\
\text { decrease uptake of GC/GT }\end{array}$ & 4 & A \\
\hline $\begin{array}{l}\text { Susswein } \\
\text { et al24 }\end{array}$ & $\begin{array}{l}\text { Retro- } \\
\text { spective } \\
\text { longitudinal }\end{array}$ & $N=768$ & $\begin{array}{l}\text { South, AAW and } \\
\text { WW who received } \\
\text { GC }\end{array}$ & $\begin{array}{l}\text { Assessed BRCA1/2 GT } \\
\text { uptake in recent } \\
\text { diagnosed and } \geq 1 \text { year } \\
\text { later }\end{array}$ & $\begin{array}{l}\text { Genetic uptake } \\
\text { by date } \\
\text { diagnosed and } \\
\text { race }\end{array}$ & $\begin{array}{l}\text { More WW pursued GT than AAW, } \\
\text { AAW recently diagnosed had a } \\
\text { higher odd of progressing to GT } \\
\text { than longer survivors }\end{array}$ & 4 & A \\
\hline
\end{tabular}

